\title{
The early fossil record of dinosaurs in North America: A new neotheropod from the base of the Upper Triassic Dockum Group of Texas
}

\author{
Sterling J. Nesbitt and Martín D. Ezcurra \\ Acta Palaeontologica Polonica 60 (3), 2015: 513-526 doi:http://dx.doi.org/10.4202/app.00143.2014
}

The dinosaur record from the stratigraphically-lowest portions of Upper Triassic deposits of western North America is poor and only consists of a handful of fragmentary hind limb elements. Here we present an articulated segment of the ankle region of a dinosaur that consists of the distal ends of the tibia and fibula and a complete astragalocalcaneum. Additionally, we suggest that an isolated femur and maxilla from the same locality may belong to the same taxon. Using the most comprehensive analysis of early theropod relationships currently available, we determined that the new specimen pertains to a coelophysoid neotheropod (i.e., more closely related to Coelophysis bauri than to Allosaurus fragilis). The stratigraphic position of the locality where the new specimen was discovered is equivalent to the famous Otis Chalk localities and this set of localities likely predates the rest of the Dockum Group and possibly the entirety of the fossiliferous portion of the Chinle Formation on the Colorado Plateau. Therefore, the new specimen represents one of the oldest neotheropods. Accordingly, neotheropods were present at or just after the onset of both the Chinle Formation and Dockum Group deposits.

Key words: Dinosauria, Archosauria, Neotheropoda, phylogeny, Norian, Otis Chalk, North America.

Sterling J. Nesbitt [sjn2104@ vt.edu], Department of Geosciences, Virginia Polytechnic Institute and State University, Blacksburg, Virginia, 24061, USA. Martín D. Ezcurra [martindezcurra@yahoo.com.ar], School of Geography, Earth and Environmental Sciences, University of Birmingham, Edgbaston, Birmingham B15 2TT, UK.

This is an open-access article distributed under the terms of the Creative Commons Attribution License (for details please see creativecommons.org), which permits unrestricted use, distribution, and reproduction in any medium, provided the original author and source are credited. 
For Full text $(566.7 \mathrm{kB})$ ।

Fof Supplementary file $(167.4 \mathrm{kB})$ 